\title{
The Effect of Cyperus Rotundus on Memory and the Number of Hippocampus Cells on Alcohol Administration
}

\author{
Heru Supriyatno", Ronal Tolkhah, Supriyadi, Shobirun, Munjiati \\ Nursing Department, Poltekkes Kemenkes Semarang. Jln. Tirto Agung Pedalangan, Banyumanik, Semarang,
} Indonesia

*Corresponding Author: Heru Supriyatno, Nursing Department, Poltekkes Kemenkes Semarang. Jln. Tirto Agung Pedalangan, Banyumanik, Semarang, Indonesia. Email: heru_semarang@yahoo.co.id

\begin{abstract}
:
Background: Cyperus rotundus is a type of weed plant difficult to eradicate that has been popular as a traditional medicine in the traditional Asian medicine.

The Objective: This study was conducted to see if Cyperus rotundus could prevent a decrease in the number of pyramidal hippocampal cells in mice due to ethanol administration.

Method: Twenty-five male Spinoque-Dowley rats aged 30 days were divided into five groups were given mineral water, 25\% alcohol, the ethanol extract of C.rotundus tuber with doses of 0.325, 0.75 and $2.5 \mathrm{gr}$. Morris water maze testing performed on the first, second, third, tenth and seventh day of treatments. The rats are euthanasia with transcardial perfusion to take the hippocampus. Calculation of hippocampal cells is done by stereology.
\end{abstract}

Result: From the Morris water maze test of hippocampal cell counting there were significant differences between groups. The highest number of hippocampus cells in the sequence are: Group 1, Group 4 and the smallest is Group 2. Similarly, Morris water maze test results of the fastest time in series are Groups 1, 4, 3, 5 and the longest 2. This condition suggests that ethanol decreases the number of hippocampal cells and decreases memory function. Also, C. rotundus has been shown to prevent a reduction in the number of hippocampal cells and avoid the decline in memory function.

Conclusion: Ethanol causes a decrease in the number of hippocampal cells and decreased memory function, and $C$. rotundus can prevent a reduction in the number of hippocampal cells and decreased memory function.

Keywords: Pyramidal hippocampus cells, Morris water maze, C. rotundus.

\section{INTRODUCTION}

The use of natural materials as traditional medicine in Indonesia has been done since many centuries ago. The high cost of health services and the price of expensive synthetic drugs cause the use of natural ingredients as medicine increasingly widespread (Karan \& Benowitz, 2000).

Cyperus rotundus is a type of plant known as an elusive weed that has been popular as a traditional medicine in traditional Indian, Chinese, Egyptian, Japanese, Sudanese and Turkish medicine. C. protundus is commonly used to treat various diseases such as the wound, hot, analgesic, rheumatic, diarrhea, vomiting, conjunctivitis, anti malaria, worm medicines, cough, alcoholism, epilepsy, depression, hypertension, and impotence (Kesner \& Rolls, 2001).

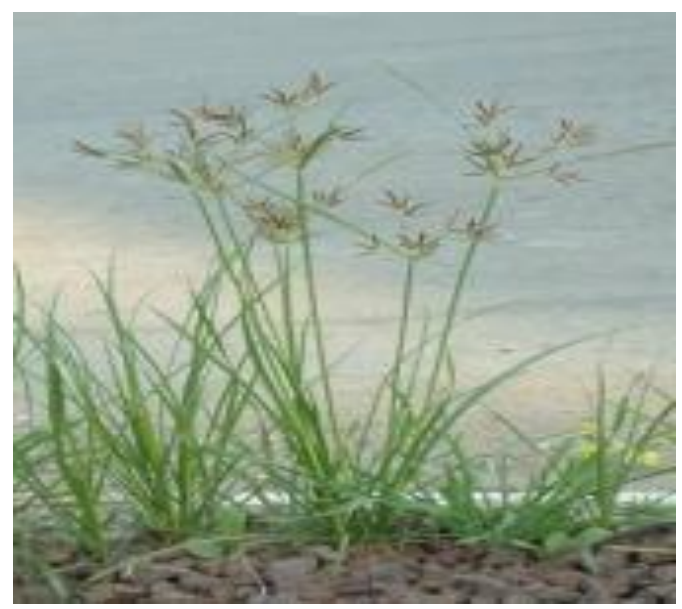

Figure1. Cyperus rotundus

Some studies suggest that C.rotundus contains five (5) essential components such as essential 
oils, terpenoids, flavonoids, glycosides, and saccharides. These five elements tested the protective effect against ethanol-induced gastric ulcers in mice. The result is a better protective effect obtained from the connected five components compared to each item individually with the same dose and concentration. The antioxidant content of C.rotundus tubers such as flavonoids and terpenoids is expected to prevent cellular damage from free radical products from alcohol metabolism (Kilani, 2005).

C.rotundus has been used as a traditional medicine for the first part of this plant is commonly used as a medication is the tuber. In preliminary chemical analyses of the roots and rhizomes of C.rotundus were found to contain $\beta$ -sitosterol, cyperene, cyperol, flavonoids, sesquiterpenoids, ascorbic acid, and polyphenols. Flavonoids, ascorbic acid, and polyphenols are known as antioxidants ( Mikolajczak et al, 2001). The highest terpenoid content in C.rotundus is Cyperyne. As antioxidant, terpenoids, and flavonoids play a role limiting the number of Reactive Oxygen Species so to prevent excessive tissue damage. Cyperyne includes a subgroup of sesquiterpene.

This study aims to examine the effects of C.rotundus tubers on hippocampal cells and memory due to alcohol use. The hippocampus is the organ responsible for maintaining short-term memory, consolidating into long-term memory, and using memory immediately after some time of the study (Puradchikody et al, 2006).

\section{Materials AND Methods}

This research is experimental using posttest control group design. Subjects were 25 male Sprague-Dawley rats, 30 days old, 100-125 gram weight, divided into five groups randomly selected.

Table1. Table of study group divisions

\begin{tabular}{|l|l|}
\hline Groups & \multicolumn{1}{|c|}{ Treatment } \\
\hline 1 & $\begin{array}{l}\text { No treatment (pure water given orally } \\
\text { dan intra peritonially) }\end{array}$ \\
\hline 2 & $\begin{array}{l}\text { 25\% Alcoholdose 2.5 gram / kg body } \\
\text { weight / day, intra peritonial + distilled } \\
\text { water orally. }\end{array}$ \\
\hline 3 & $\begin{array}{l}\text { 25\% Alcohol dose 2.5 gram / kg body } \\
\text { weight / day, intra peritonial + oral } \\
\text { ethanol extracts from C.rotundus tubers } \\
\text { dose 0.325 gram / kg body weight / day }\end{array}$ \\
\hline 4 & $\begin{array}{l}\text { 25\% Alcohol dose 2.5 gram / kg body } \\
\text { weight / day, intra peritonial + oral } \\
\text { ethanol extracts from C.rotundus tubers } \\
\text { dose 0.75 gram / kg body weight / day }\end{array}$ \\
\hline 5 & $25 \%$ Alcohol dose 2.5 gram / kg body \\
\hline
\end{tabular}

weight / day, intra peritonial + oral ethanol extracts from C.rotundus tubers dose 1.5 gram / kg body weight /

The tool used for measuring Spatial Memory is the Morris water maze and painting of hippocampal pyramidal cells is with Cresyl violet. The preparations are observed by using a 400x light magnification microscope. The number of pyramidal cells is calculated by using the stereology method.

\section{RESULT AND DISCUSSION}

The samples used in this study were 25 rats divided into 5 (five) groups of each group consisting of 5 (five) mice selected randomly. At the end of the treatment, all mice are measured by weight, the weight of the cerebrum and the weight of the cerebellum.

ANOVA statistical analysis of weight, cerebellum weight, and inter-group cerebellum weight showed no significant differences. The significance of body weight between groups is $p$ $=0.067$, the significance of cerebrum weight between groups $\mathrm{p}$ is $=0.437$, and weight significance of cerebellum between groups is $p$ $=0.195$. This figure shows that the difference in treatment performed did not affect the weight of cerebrum. This phenomenon means that the difference in weight, weight of cerebrum and weight of cerebellum does not affect the results of Morris water mize test.

The results of this study indicate that between groups there are significant differences $\mathrm{p}=$ 0.001. This figure suggests that the different treatments lead to differences in the healing time of each cluster. This condition implies that treatment differences cause disturbances in short-term memory.

While in the analysis of memory persistence test showed that between groups there was no significant difference $p=0.330$. This indication suggests that treatment differences do not cause disturbances in long-term memory.

In the cell, coun $t$ calculation indicates that CA1 cell count is no significant difference $(\mathrm{p}=$ 0.002) between the three groups. Similarly, counting of CA2 and $\mathrm{C} 3$ cell counts was no significant difference $(p=0.001)$ between the three groups. This suggests that treatment differences lead to significant differences in the number of intercellular groups between CA1, $\mathrm{CA} 2$, and CA3. 
The Effect of Cyperus Rotundus on Memory and Administration

Alcohol can cause oxidative stress because alcohol can increase the oxidant level of ROS and decrease the number of antioxidants. The formation of excessive ROS is the reason why brain cells are especially sensitive to oxidative stress. Because in brain cells a lot contains polyunsaturated fatty acids which are a target that is susceptible to damage due to oxidative stress due to the ownership of unsaturated bonds (Guyton,\& Hall, 2000).

Ethanol increases ROS directly through mitochondrial respiration by forming superoxides, hydroxyl radicals, and nitrogen radicals. Chronic alcohol consumption leads to thiamine deficiency which is an essential nutrient required by all cells including the brain.

The presence of oxidative stress sequestered by ROS formation by alcohol can damage cells and trigger cell death through mitochondrial damage. Mitochondria are energy-producing organelles that play a significant role in the regulation of calcium levels in cells. High levels of intracellular calcium are toxic to neurons. When there is mitochondrial dysfunction, there is a process called Mitochondrial Permeability Transition (MPT). In this process, holes form on the mitochondrial membrane so that the mitochondria can release the calcium and cytochrome into the cytosol neuron. Both calcium and cytochrome can activate a causative that can trigger apoptosis (Achyad, \& Rosyidah, 2000).

In various studies, flavonoids are potent antioxidants capable of cleansing hydroxyl radicals, superoxides and lipid peroxide radicals (Kilani, 2005). Flavonoids exhibit antioxidant effects because they can form antioxidantderived radicals to be stable. Effects of flavonoids in the brain in several ways as follows: (1) inhibit the production of free radicals. (2) capture free radicals, (3) interrupt the peroxidation process, and (4) strengthen endogenous antioxidant defenses.

Experiments on terpenoids as antioxidants have been conducted among others research on the antioxidant effects of $C$. rotundus extracts can inhibit superoxide formation, also play a role in inhibiting oxidative stress (Kiernan, 1998).
Citation: Hery. Supriyatno, Ronal,Tolkhah, Supriygdi, Memory and the Number of Hippocampus Cells on Alcohol Admi Healthcare. 2017; 3(2): 15-17. doi: dx.doi.org/ 10.20431/2455-4324.0

Copyright: (C) 2017 Authors. This is an open-access article dist Commons Attribution License, which permits unrestricted use, distrib provided the original author and source are credited.

\section{CONCLUSION}

The group given alcohol and ethanol extract of C.rotundus tubers had a larger number of cells than the alcohol-only group, and the group given alcohol and ethanol extract of C.rotundus tubers had better spatial memory than the only group given alcohol only. But further research is needed to refine the design and methodology with human research objects further so that C.rotundus are safe to be used as alternatives medication.

\section{REFERENCES}

[1] Achyad, D. E. \& Rosyidah, R. 2000. C. rotundus, Cyperus rotundus L. Asiamaya dotcom Indonesia, Jakarta. http:// www.asiamaya.com/jamu/isi/ C.royundus cyperusrotundus.html.

[2] Guyton, A. C., \& Hall, J. E. 2000. The Cerebral Cortex; Intellectual Functions of The Brain: Learning and Memory, Textbook of Medical Physiology, $10^{\text {th }}$ edition, Philadelphia.

[3] Karan, L. D., \& Benowitz, N. L. 2000. Substance Abuse, Dependence and Treatment, Clinical Pharmacology Basis Principles in Therapeutic, ed Carruthers, S. G., I-Hoffman, B. B., Melmon, K. C,4" edition, New York.

[4] Kesner, R. P., \& Rolls, E. T. 2001. Role of Long Term Synaptic Modification in Shorth Term Memory, Hippocampus, 11: 240-50.

[5] Kiernan, J. A. 1998. Limbic System Hippocampus and Amygdala, Barr's The Human Nervous System An Anatomical View Point, $7^{\text {th }}$ edition, Philadelphia.

[6] Kilani, S. 2005. Chemical Composition, Antibacterial and Antimutagenic Activities of Essential Oil from Cuperus rotundus. Journal of Essential Oil Research. 4091(11).

[7] Mikolajczak, P., Kozaryn, L., Nowaczyk, M., \& Kaminska, E. 2001. Ethanol Facilitation ShortTerm Memory in Adults Rats with a Disturbed Circadian Cycle, Alcohol \& Alcoholism, 36(4): 292- 97.

[8] Puradchikody, A., Nithya, D.C. \& Nagalakhsmi, G. 2006. Wound healing activity of cyperus rotundus linn. Indian Journal of Pharmaceutical Sciences. 68:97-101. 
The Effect of Cyperus Rotundus on Memory and the Number of Hippocampus Cells on Alcohol Administration 